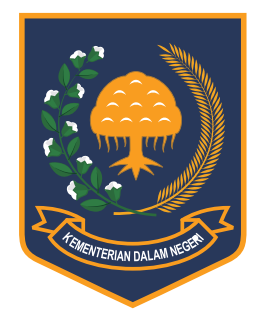

JURNAL BINA PRAJA

e-ISSN: 2503-3360 | p-ISSN: 2085-4323

Accreditation Number

21/E/KPT/2018

http://jurnal.kemendagri.go.id/index.php/jbp/index

\title{
INSTITUTIONAL OPTIMIZATION STRATEGY of CAPITAl InVESTMENT Agency AND ONE-STOP INTEGRATED SERVICE
}

\author{
Eko Subowo*, Syamsul Maarif, Yandra Arkeman, Kirbrandoko \\ School of Business, Bogor Agricultural University
}

Received: 16 July 2019; Accepted: 26 September 2019; Published online: 8 November 2019

DOI: $10.21787 / j b p .11 .2019 .237-248$

\begin{abstract}
Licensing is one way for business actors to formalize business. Without licensing, businesses are unable to move to the formal sector and get a variety of benefits such as coaching programs, tax incentives and getting credit or capital assistance, especially from banks and legal guarantees. Nevertheless, business operators consider that licensing services are still not optimal. Business actors' complaints include inefficient and effective services caused by weak institutional aspects. Institutional improvement of the Capital Investment Agency and the One-Stop Integrated Service (DPMPTSP) to reach the prime point will have an impact on the ease of service and improve the investment climate. The main method used in this study is the Regulatory Impact Assessment (RIA) supported using Regulatory Mapping (Regmap) to determine the regulatory map that contributes to the institutional aspects of DPMPTSP. The results of the analysis revealed that the root cause of the weakness of DPMPTSP's institutions was the absence of DPMPTSP's institutional improvement program. The root causes of these problems contribute to some of the problems in optimizing DPMPTSP institutions such as the Standard Operational Procedure (SOP) that is not updated, the lack of competence of the implementing apparatus, the delay in anticipating changes in regulations of the central authority. Alternative corrective actions from the results of the analysis are the devolution of authority for licensing services, preparation of guidelines for Standard Procedure Norms Criteria (NSPK), institutional regulation updates, preparation of local regulations related to institutional implementation, SOP formulation of licensing services, placement of technical human resources, and development of infrastructure facilities.
\end{abstract}

Keywords: DPMPTSP, Licensing, Regulatory Impact Assessment (RIA).

\section{INTRODUCTION}

The implementation of regional government in Indonesia through the implementation of the principle of decentralization is intended to develop Indonesia from the regions by realizing new economic growth clusters. One of the goals of decentralization is to internalize democratic values to the lowest levels of government (Bünte, 2008, p. 114).

Public services tend to reflect the political factors and institutional behavior of government organizations (Hodgkinson, Hannibal, Keating, Chester Buxton, \& Bateman, 2017, p. 999). This concept needs to be completed so that it can illustrate the dynamic and interconnection side of the modern public service system. The concept of contemporary public service requires the involvement of many stakeholders, both directly and indirectly, that cannot be isolated but is part of a broader ecosystem (Jaakkola, Helkkula, \& AarikkaStenroos, 2015, p. 2). To be able to provide quality public services, good public sector management is needed. The delivery of public services requires a complicated governance system and is not only determined by an organization individually (Osborne, Radnor, Kinder, \& Vidal, 2014, p. 323).

Development in the context of realizing community welfare so far still relies on funding sourced from the State Budget (APBN). The fiscal Year 2019 states that the budget deficit target is planned at IDR297,163.3 billion or 1.84 percent of GDP (Republik Indonesia, 2019, p. 4). Seeing this

\footnotetext{
* Corresponding Author

Phone : +6281315149729

Email : eko.subowo@gmail.com
} 
fact, we need another source of funds for national development costs, one of which is by attracting investment.

Improving the investment climate needs to be done to improve the ease of doing business so that capital owners feel comfortable investing in Indonesia. Investment attractiveness will arise if the government can facilitate the ease of investors in starting business activities. The right, fast, easy, and affordable licensing for business actors also determines the realization of investment commitments. Improving the investment climate and economic growth needs to be supported by easy, inexpensive and fast licensing service mechanisms (Mulyadi, 2018, p. 124).

Licensing institutions in Indonesia have experienced changes marked by the presence of Permendagri No. 24 of 2006, Permendagri 20 of 2008, Permendagri 100 of 2016, and Permendagri No. 138 of 2017. The amendments are intended to improve the quality of licensing services. The improvement in the quality of service can be seen from the easier processing of permits; concise and quick procedures.

The DPMPTSP Institution still has many problems to this day. This can be seen from the fact that there are still ineffective and efficient licensing services (KPPOD, 2016, p. 6). There are still business operators, especially micro and medium enterprises, having difficulty accessing licensing services (Hartono \& Hartomo, 2016, p. 25). DPMPTSP's institutions are strongly influenced by regulations/policies in the field of public services and licensing. Therefore, institutional optimization can be done by applying the RIA method. The RIA analysis method is considered appropriate in improving the quality of government policies to produce better governance and development policies (Biro Hukum Kementerian PPN/Bappenas, 2011, p. 5). This method can help researchers ensure that regulations can be applied effectively and efficiently (OECD, 2008, p. 4).

The ease of licensing services provided by the Government is closely related to the posture and institutional structure of the licensing service implementing organization. To support this optimal service, the Government formulated an institution in the form of the Capital Investment Agency and OneStop Integrated Services (DPMPTSP). DPMPTSP can be a strategic element in improving the quality of public services and strengthening interconnected investments to encourage regional competitiveness.

DPMPTSP institutional quality improvement is also inseparable from the existence of bureaucratic reform that aims to reduce and ultimately eliminate any misuse of public authority by officials in the related agencies; making Indonesia the country with the most-improved bureaucracy; improve the quality of service to the community; improve the quality of formulation and implementation of agency policies; improve efficiency (cost and time) in carrying out all aspects of organizational tasks; making the Indonesian bureaucracy anticipatory, proactive, and effective in dealing with globalization and the dynamics of strategic environmental change (KPPOD, 2014, p. 3).

This is in line with the improvement in the performance of licensing services aimed at creating convenience for business actors. In the context of public sector services, the costs incurred include three things (Mardiasmo, 2009, p. 125), namely: (1) input costs which are resources that need to be allocated to provide services; (2) output costs which are costs incurred to deliver the product (in the form of licensing documents) to the business actors as the applicant; and (3) process costs measured by considering organizational functions.

Managerial competence and organizational capability influence organizational effectiveness, both of which contribute significantly even though the impact of organizational capability is greater than managerial competence (Rangriz \& Soltanieh, 2015). The government has tried to encourage improvement in the quality of DPMPTSP prime institutions. This effort is reflected in the issuance of Permendagri No. 138/2017 about the DPMPTSP Institutions. This Regulation of the Minister of Home Affairs encourages business process efficiency in licensing services using electronic systems. The benefits of this electronic system are not only beneficial for businesses, but also for the Government, especially in the regions. For LGs, optimizing electronic systems will streamline procedures as well as requirements that must be checked. For business people, the application of an electronic system will make it cost-efficient to be incurred, because it is enough to upload it into the system so that licensing can be processed.

Good regulation also plays a role in creating a good investment climate. Regulations that are friendly to entrepreneurship and efficient to business are the determinants that influence the entry of FDI (Vogiatzoglou, 2016, p. 359). The impact of a country's business regulations on the attractiveness of foreign investment can be seen in the Ease of Doing Business rating of the World Bank, the rating has a significant effect on FDI, which is driven by the Ease of Trading Across Borders component (Corcoran \& Gillanders, 2015).

This research on DPMPTSP institutions is expected to find a solution for strengthening DPMPTSP institutions. This research was also 
strengthened by the situational analysis of regulations related to DPMPTSP institutions. This approach is different from previous studies that raise issues based on regulatory studies or literature studies. The focus of this research relates to strengthening the institutional aspects of DPMPTSP as an agency implementing licensing services. The institutional aspect also forms the basis for the analysis and determination of solutions to be carried out in this study.

\section{METHOD}

\section{A. Situational Analysis Stage}

This stage begins with a literature study, which is conducting a literature review from various research reference sources such as books, scientific publications (journals), regulations and reports, as well as information from printed and electronic media. A literature study is carried out by synthesizing various information and theories relevant to research. Also, a literature study is very useful to identify problems, strengthen theoretical frameworks and build concepts that might be developed in research. The next step is to conduct in-depth and structured interviews using interview guidelines to 10 informants who were selected by purposive sampling based on consideration of expertise and its relationship with licensing services.

Descriptive statistical analysis is used as a quantitative approach to present primary data processing results obtained from FGDs and indepth interviews with practitioners consisting of policymakers, experts, providers and users of licensing services. The analysis provides a situational picture regarding the licensing process and DPMPTSP's institutional quality. A comparative approach is also used to compare applicable policies with facts and implementation practices in the field.

\section{B. Regulatory Mapping}

Regulatory Mapping (RegMap) was chosen as a tool to monitor and evaluate policies and regulations related to licensing services. Regulatory Mapping is conducted in 4 (four) stages. Mapped substances are various regulations and policies issued by the government and regional governments. At this stage, overlapping, conflicting, and incomplete policies are in inventory. Mapped policies include Laws, Government Regulations (PP), Presidential Regulations (Perpres), Ministerial Regulations (Permen), and Regional Regulations (Perda).

\section{Regulatory Impact Assessment (RIA)}

The use of RIA in this study is intended as a method to obtain the best options for institutional strengthening measures for DPMPTSP. In this study, the RIA stage is only limited to the selection of alternative action options which is the 5th step of the overall RIA stage. This relates to the purpose of this study which only yields possible action options based on the greatest net benefit. Consideration of the estimated benefits and costs is made for each action option and the impact that will be received by all stakeholders, both directly and indirectly.

\section{RESULTS AND DiSCUSSION}

\section{A. Licensing Institutional Situation in Indonesia}

Since it was mandated to be established in Law Number 23 of 2014, the One-Stop Integrated Service (PTSP) as a public service and licensing organization has become a mandatory requirement for all local governments. The formation of the organization is carried out as part of the obligations of regional heads in providing public services and excellent licensing to the community. PTSP was formed as part of realizing good governance through the implementation of public services in the fields of licensing and non-licensing. Implementation of public services for licensing is the entire process starting from the application process until the issuance of a permit. As a form of protection and legal certainty, a delegation of licensing authority that was previously in the hands of the Regional Head/Institution or Agency that has licensing authority is delegated to the Head of Provincial and Regency/City's PTSP.

The licensing service through PTSP is intended to shorten and simplify the licensing process. The delegation of all licensing services to the PTSP will be followed by simplifying service procedures that are expected to cut business processes so that they will automatically improve service quality, which is reflected in more efficient procedures. Also, the implementation of licensing and non-licensing through PTSP is very important as an entry point for investment and business investment (Hidayat, Sutomo, \& Sunarko, 2018, pp. 151-152). Broad access to get excellent service from the center to the regions with the support of electronic services can provide convenience to the community. The ease in managing this permit will be an attraction for investors to start business activities in Indonesia (KPPOD, 2016, p. 4).

In the context of increasing the ease of doing that was proclaimed by the President, the role of 
PTSP was further strengthened by the establishment of administrative sanctions and criminal sanctions for Regional Heads who did not provide licensing services according to the provisions. The Ministry of Home Affairs, in this case, as the party that will take over the authority of the Provincial Head, while the Governor as the representative of the Central Government will take over the authority of the Regent/Mayor.

Relating to the organizational structure in line with the typology of regional apparatus organizations as mandated by Government Regulation Number 18 of 2016 on Regional Apparatuses. Based on the typology, PTSP can be formed as a Service/Agency/Office/Unit of PTSP. The merger of PTSP with the Investment Agency, as stipulated in Permendagri Number 100 of 2016, is part of the institutional strengthening of PTSP. The PTSP and the Investment Agency are considered to have duties and functions that are compatible and mutually supportive, and nominatively adjusted to the Capital Investment Agency and One-Stop Services (DPMPTSP).

The licensing process carried out by DPMPTSP is closely related to the Ministry/Agency (K/L). These institutions hold the authority as the drafting of licensing service regulations and Norms of Standard Procedure Criteria of each sectoral affair. If related to the institutional level of public services raised by Nee, the K/L has institutional arrangement authority in setting formal regulations that will be used as a basis for DPMPTSP at the middle level in determining investment licensing (Nee, 2003).

Problems encountered at this time is that the preparation of the NSPK still refers to the legislation in each sector so that it cannot yet be integrated with an electronic-based licensing service system as regulated in PP 24 of 2018.

The delegation of authority of K/L sectoral affairs to the Technical Service/Agency results in the issuance of sectoral licensing which cannot be done by DPMPTSP alone. Sectoral ego and weak $\mathrm{K} /$ L's trust to delegate authority to DPMPTSP in implementing NSPK are some of the factors why DPMPTSP is not optimal as an integrated licensing agency. Besides, this is often a factor that slows the licensing process.

The relationship between DPMPTSP and other stakeholders such as K/L, Technical Agencies, Business Consultants who are consultative causes the licensing process to become more complicated. This is in line with the statement of broader organizational relations and involving many parties which will require more complex institutional analysis (Kusdi, 2009, p. 30).

DPMPTSP only acts as an administrative licensing organization, with no technical authority in the permit issuance process. If related to elements of the management system, the role of DPMPTSP can be said to be still at the stage of receiving input and processing output in the form of effective permits (Amsyah, 2001, p. 27). While the data processing still involves a lot of the Technical Agency. This resulted in ineffective licensing processes and weakened the role of DPMPTSP.

The increase in investment value in Indonesia will continue to show a positive trend with the establishment of a good public service delivery system (BKPM, 2019). One that has been developed in public services in Indonesia is Online Single Submission (OSS) based licensing. OSS was built to make it easy for investors to register or apply for a business license through a simplified licensing process that can be carried out anywhere.

Licensing service is a sector that deals directly with the community/groups/businesses that demand good service standards. This needs support from human resources who carry out direct services, bearing in mind the process of issuing business licenses is a series of processes that involve many parties, plus the service process is not entirely using electronic methods so that the person to person process is still being carried out.

The quality of public services is closely related to the quality of human resources (Raymond, Hatane, \& Hutabarat, 2015, p. 2). To be able to achieve good public services, it is necessary to support human resources who have competence and capability in carrying out procedures, effective communication and the ability to build a positive work climate in the licensing service process. Quality of service supported by good human resources will improve organizational performance which has an impact on increasing the confidence of the community and business people.

\section{B. Map of Investment Licensing Regulations}

From RegMap, it is known that there are 48 regulations related to licensing that is still valid today. The results of filtering regulations are known to be 8 regulations governing DPMPTSP Institutions, while the regulations relating to the Delegation of Authority are 24 regulations. The regulation is a legal umbrella for the delegation and implementation of basic business licenses that are served by DPMPTSP such as Trade Business License (SIUP), Company Registration Certificate (TDP), Building Construction Permit (IMB), and Tourism Business Registration Certificate (TDUP).

Not only from the institutional side but the current regulatory aspects must also be a concern. The Deputy for Economic Affairs of the State 
Secretariat stated that the problematic laws and regulations were also one of the problems that hindered investment and specifically impeded the implementation of OSS (Article 62 PP 24/2018).

Regulation plays an important role in creating investment ease. The results of an interview with the Chairman of the Chamber of Commerce and Industry obtained information that in addition to the ease in licensing, a legal certainty was needed to invest in Indonesia. Investors hope that the regulations governing licensing and investment in Indonesia will not change quickly. Strong regulation will foster investor confidence in carrying out investments in Indonesia.

At present, the highest regulation regarding PTSP institutions is regulated through Law No. 23 of 2014 on the Regional Government. According to article 350 paragraph (2), regional governments are required to provide licensing services by the provisions of the applicable legislation. Still, in the same article, there are provisions on sanctions for regional heads who do not provide services in the form of administrative sanctions and even the authority of the licensing service will be taken over by the Minister of Home Affairs if they do not also carry out after the sanctions. To carry out the licensing service, Article 350 paragraph (3) states that the regions then form a one-stop integrated service unit (PTSP).

At the PP level, PTSP institutional posture is also regulated through PP No. 18 of 2016 concerning Regional Apparatuses. This PP regulates the organizational structure of licensing service implementers based on scoring the region's ability to finance institutions and workloads. Even though the nomenclature is the same, the organizational structure of DPMPTSP varies in each region.

According to articles 17 and 39 PP No. 18 of 2016, an evaluation of the PTSP institutional is based on the number of scoring with a minimum amount of 401 . With the scoring standard, it is also regulated regarding the number of fields in regional apparatus organizations (OPD). If the scoring for the area is less than the standard, the OPD structure only consists of 3 fields. The implementation of investment affairs is also based on a family of affairs.

Regulations on the nomenclature of agencies conducting licensing and investment services in the regions are also regulated in Minister of Home Affairs Regulation No. 100 of 2016 on the Nomenclature Guidelines of Provincial and Regency/City's Capital Investment Agencies and Integrated One-Stop Services (DPMPTSP). This regulation regulates in more detail the implementing organizational structure, division of tasks, technical teams and functional positions.
Generally, DPMPTSP structures in the regions consist of Heads of Offices, Secretariat, Sectors, Sections, and Functional Positions. The entire structure has each function which is coordinated by the Head of Service. All the local regulations on the institutions studied were not in harmony with the central regulations that were in effect at the time the regulation was issued.

A more detailed regulation governing DPMPTSP institutions is Minister of Home Affairs Regulation No. 138 of 2017 on the Implementation of One-Stop Integrated Services. This Regulation of the Minister of Home Affairs is a guideline for the implementation of DPMPTSP in the regions. The target to be achieved through the issuance of this regulation is the realization of DPMPTSP implementation that is fast, easy, transparent, certain, simple, affordable, professional, with integrity and increases the community's right to obtain Licensing and Non-Licensing services. Permendagri No. 138 of 2017 has several provisions, including institutional, authority, public service standards, management, and management of information and public complaints. The provisions stipulated in the Permendagri are enough for optimal licensing service implementation.

Arrangements for licensing in the regions are determined through Regional Regulations. To date, 39 local regulations (perda) are regulating DPMPTSP institutions and authorities. 27 regional regulations form the basis of DPMPTSP institutions. The Regional Regulation was issued in the period 2008 to 2018. The regulations which form the basis for DPMPTSP institutions in the regions govern the position, composition, organization, duties, and functions. In most local regulations, DPMPTSP is domiciled to help the Regional Head carry out Investment affairs. A coordination line was also established so that the licensing services carried out by DPMPTSP could run well.

The mapping results of DPMPTSP regulations show that there are still local regulations and regional heads that have not yet adjusted central regulations, especially regarding institutional licensing services. This can be seen from the fact that there are still old regulations that are used as a basis or legal umbrella for DPMPTSP implementation. For this reason, renewal or updating of the local regulation is needed, one of which is in juridical reference. In more detail, issues related to DPMPTSP institutional suboptimal can be described in Figure 1.

The formulation of the problem tree above shows that the root of the DPMPTSP institutional's suboptimal is the absence of a DPMPTSP institutional improvement program.

\section{Institutional Optimization Strategy of Capital Investment Agency




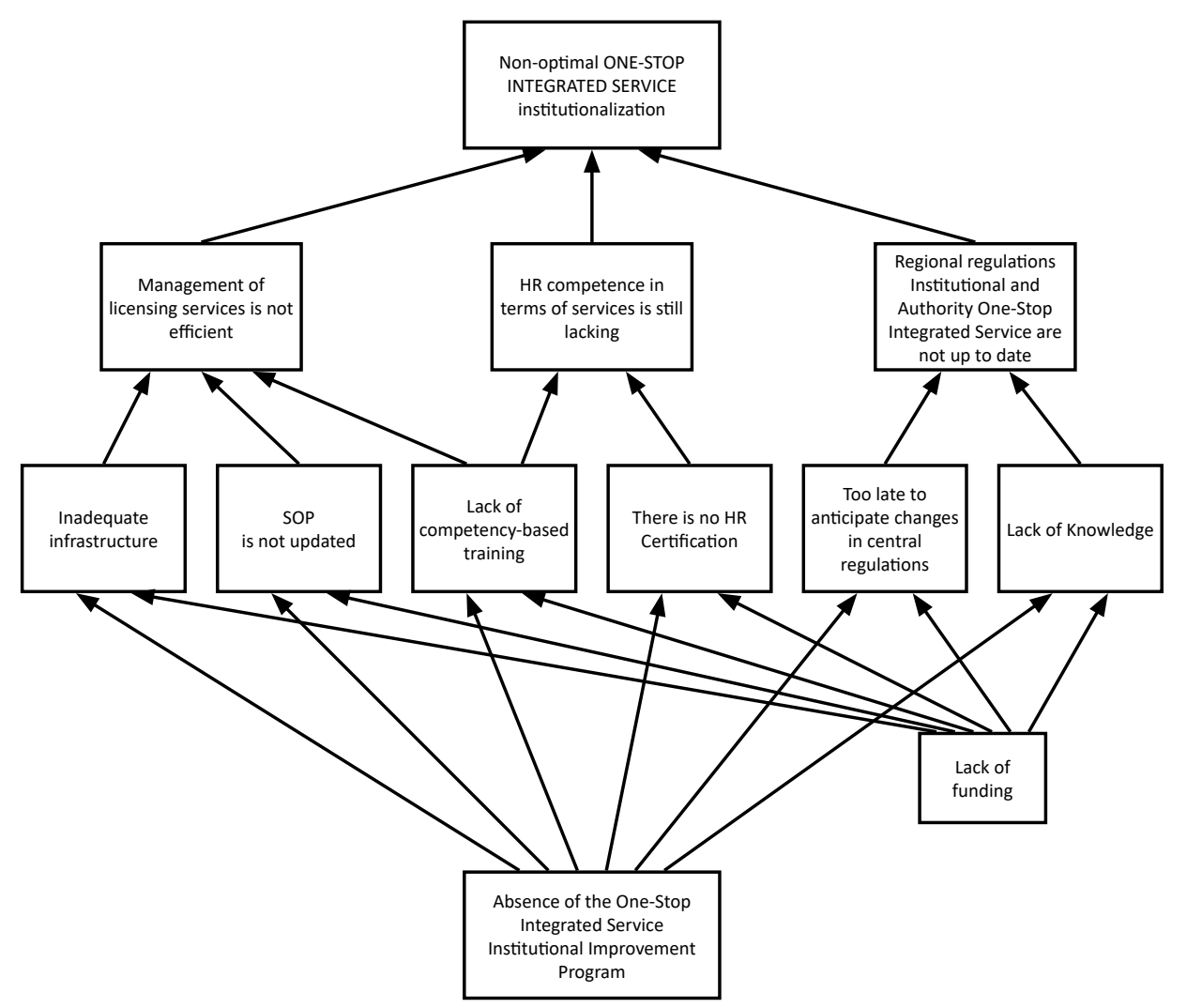

Figure 1. Diagram of ONE-STOP INTEGRATED SERVICE Institutional Optimization Problem Formulation

Each of these problems occurs because of several interrelated things. Besides, the cause of the problem is the behavior of several parties that can trigger the problem. The behavior that contributes to each of these actors can be seen in Table 1 .

Based on the problems that have been described previously, the general goal to be achieved is "Optimizing DPMPTSP institutions". The specific purpose of realizing this general goal is to change the behavior of stakeholders/actors who play a role in DPMPTSP institutions. Specific objectives that are expected to change the behavior of stakeholders that encourage optimization are as follows:

1. Providing regulations for DPMPTSP institutions;

2. Increase supporting capacities such as infrastructure, systems, human resources, and budget;

3. Encourage increased coordination with the Technical Service to achieve the planned service targets;

4. Provide competency capacity building programs.

Table 2 is an identification of the objectives of the policy formulation on the improvement of DPMPTSP Institutional optimization.

To achieve the policy objective "Optimizing DPMPTSP Institutions", various alternative actions were formulated. Alternative actions that are relevant to take include designing a program of activities to increase the capacity of human resources, increasing the ability to support infrastructure, optimizing the coordination of various agencies related to licensing services, and issuing regulations at the central and regional levels as a follow-up. The alternative action options that can be chosen are as follows:

\section{1) Do Nothing/Leave it as it is:}

If this option is selected, there will be no change in the institutional conditions of DPMPTSP which are expected to be optimal in providing services. The authority of DPMPTSP is still weak, there are not enough human resources, and inadequate infrastructure will still emerge. In the end, the services provided cannot meet expectations, especially business actors as service recipients. Some of the risks that may arise from this option are:

a. Licensing service procedures are still complicated;

b. Obtaining permits still require many requirements;

c. Business actors still require a long time;

d. Potential for corruption because existing procedures still allow the meeting of PTSP employees and permit applicants. 
Table 1.

Problem Formulation

\begin{tabular}{|c|c|c|c|c|}
\hline \multirow{3}{*}{$\begin{array}{l}\text { Problem Root } \\
\text { Identification }\end{array}$} & \multicolumn{4}{|c|}{ Sub-Optimal DPMPTSP Institutional } \\
\hline & \multirow{2}{*}{ Cause } & \multicolumn{3}{|c|}{ Influential Parties/Behavior/Motivation } \\
\hline & & Actors involved & Donating Behavior & Motivation \\
\hline $\begin{array}{l}\text { Licensing procedures are } \\
\text { inefficient }\end{array}$ & $\begin{array}{l}\text { - Supporting } \\
\text { infrastructure is } \\
\text { incomplete } \\
\text { - SOP of service is } \\
\text { outdated } \\
\text { - Lack of DPMPTSP } \\
\text { Institutional } \\
\text { Improvement }\end{array}$ & $\begin{array}{l}\text { - DPMPTSP } \\
\text { - Technical Agency }\end{array}$ & $\begin{array}{l}\text { - Weak coordination } \\
\text { between DPMPTSP and } \\
\text { the Sector Agency } \\
\text { - Lack of budget due to } \\
\text { lack of focus planning }\end{array}$ & $\begin{array}{l}\text { - There is a Sectoral Ego } \\
\text { - Development priorities } \\
\text { take precedence in } \\
\text { budgeting }\end{array}$ \\
\hline $\begin{array}{l}\text { Human Resources } \\
\text { Competence in Services is } \\
\text { lacking }\end{array}$ & $\begin{array}{l}\text { - Lack of Training } \\
\text { - Unsuited Educational } \\
\text { background }\end{array}$ & $\begin{array}{l}\text { - } \text { DPMPTSP } \\
\text { - } \text { DPKAD } \\
\text { - Bappeda }\end{array}$ & $\begin{array}{l}\text { - Planning is not focused } \\
\text { - The process of } \\
\text { recruiting the } \\
\text { implementing } \\
\text { apparatus is not proper }\end{array}$ & $\begin{array}{l}\text { Less budgeting because } \\
\text { it is focused on regional } \\
\text { priority programs }\end{array}$ \\
\hline $\begin{array}{l}\text { The DPMPTSP Institutional } \\
\text { and Authority Regional } \\
\text { Regulation is outdated }\end{array}$ & $\begin{array}{l}\text { - Poor socialization } \\
\text { - The process of } \\
\text { formulating Local } \\
\text { Regulations is yet to } \\
\text { complete } \\
\text { - Regional Head } \\
\text { Commitment is lacking } \\
\text { - Lack of budget to } \\
\text { follow up or update } \\
\text { local regulations }\end{array}$ & $\begin{array}{l}\text { - Central Government } \\
\text { - Local Government } \\
\text { - DPRD } \\
\text { - Regional Heads }\end{array}$ & $\begin{array}{l}\text { Local governments do } \\
\text { not have the initiative to } \\
\text { update regulations related } \\
\text { to PTSP }\end{array}$ & $\begin{array}{l}\text { New central regulations } \\
\text { socialization activities are } \\
\text { still minimal }\end{array}$ \\
\hline Influence on DPMPTSP & $\begin{array}{l}\text { - DPMPTSP can provide b } \\
\text { - Speed of service can be } \\
\text { - DPMPTSP coordination }\end{array}$ & $\begin{array}{l}\text { etter services } \\
\text { guaranteed } \\
\text { with the Sector Agency can }\end{array}$ & better & \\
\hline Stakeholders' Perception & $\begin{array}{l}\text { - DPMPTSP services are s } \\
\text { - complicated manageme }\end{array}$ & $\begin{array}{l}\text { till slow } \\
\text { nt procedures, high costs, }\end{array}$ & $d \cdot$ DPMPTSP lacks socializati & ion to business actors \\
\hline
\end{tabular}

\section{2) DPMPTSP Institutional Strengthening:}

Institutional strengthening of DPMPTSP becomes an alternative, bearing in mind that one of the causes of DPMPTSP's institutions is not optimal due to the lack of institutional strength. This can be seen from the still weak coordination between DPMPTSP and the technical office, especially about the permit issuance process that requires technical team recommendations.

Some activities or programs that can be carried out in the framework of strengthening DPMPTSP capacity and institutions, such as:

a. Delegates overall licensing service authority to PTSP;

b. RegulatoryupdatesgoverningDPMPTSP Institutions that contain DPMPTSP Duties and Functions including coordination with the Technical Service; c. Making legislation to implement regulations on institutions;

d. Updating licensing service SOP.

\section{3) DPMPTSP Capacity Strengthening}

One of the causes of DPMPTSP's institutional failure in providing services is due to the lack of DPMPTSP capacity in terms of infrastructure quality and inadequate personnel support.

DPMPTSP Capacity Strengthening can be done in several ways, including:

a. Increasing the competence of the implementing apparatus (Training, Comparative Study and Certification);

b. Improving the quality of supporting infrastructure (Computers, Internet, Equipment and others);

c. Increasing the budget for supporting equipmentsupply 
Table 2.

Policy Objectives Identification

1. Section of Issues to be resolved: Institutional DPMPTSP is not optimal

2. Targets to be achieved: Optimization of DPMPTSP Institutions in providing services

3. Actor and Behavior

\begin{tabular}{|c|c|}
\hline Main Actor & $\begin{array}{l}\text { - } \text { Regional Head } \\
\text { - } \text { DPMPTSP } \\
\text { - } \text { Bappeda } \\
\text { - } \text { Department of Industry and Trade } \\
\text { - Legal Section } \\
\text { - } \text { DPRD } \\
\text { - NGOs }\end{array}$ \\
\hline Expected Behavior & $\begin{array}{l}\text { - DPMPTSP is more efficient and effective in providing licensing } \\
\text { services } \\
\text { - Bappeda appropriately plans to increase the capacity of } \\
\text { DPMPTSP and its personnel } \\
\text { - The Regional Head commits to increase the institutional } \\
\text { optimization of DPMPTSP }\end{array}$ \\
\hline \multicolumn{2}{|c|}{ 4. Supporting and Hindering Factors } \\
\hline Supporting parties and roles & $\begin{array}{l}\text { - Central Government through granting strengthening program } \\
\text { funds (through DAK and Dekon-TP) } \\
\text { - The commitment of Regional Heads } \\
\text { - DPRD Support } \\
\text { - Input from NGOs } \\
\text { - Input from the Business World }\end{array}$ \\
\hline Hindering parties and roles & $\begin{array}{l}\text { - Weak Commitments of the regents } \\
\text { - No supports from DPRD }\end{array}$ \\
\hline Supporting Factors & $\begin{array}{l}\text { - A strong desire to provide convenience in licensing services } \\
\text { - Commitments from the Regional Heads } \\
\text { - Encouragement from the business world }\end{array}$ \\
\hline Hindering Factors & $\begin{array}{l}\text { - Sectoral Ego } \\
\text { - Inadequate infrastructure } \\
\text { - Incompetent human resource }\end{array}$ \\
\hline
\end{tabular}

The identification of these options is then continued by analyzing the costs and benefits of each option to choose alternative actions. Benefit analysis is carried out to see the various uses that arise from each action. While the cost analysis is done to see what the burden or loss is borne by the community from the implementation of a single action. This cost-benefit analysis is carried out for all predetermined action options. The best action option is the one with the biggest net benefit compared to other options.

The first step in the analysis of costs and benefits is to determine the indicators of benefits or costs received by each stakeholder if each alternative action is taken. The amount of benefits or costs is measured by a score index with a scale of -3 to 3 . A positive number indicates the benefits obtained by each stakeholder, and a negative number indicates the costs borne by the stakeholders. While the number 0 (zero) indicates no costs or benefits (neutral), or the condition does not change. The greater the number means the greater the benefits obtained, and the smaller the number means the costs incurred are greater, as shown in the Table 3.

The calculation and comparison of the benefits and costs analysis of the four alternative actions are described in the Table 4.

For more details, here is a summary of costs and benefits for each alternative based on the above analysis:

1) Alternative Option I: Do nothing/Leave it as it is The decision to take the Do-Nothing option; the benefits and costs that arise if the Do-Nothing option is taken are: 
Table 3.

Cost-Benefit

\begin{tabular}{|c|c|c|}
\hline Benefit & Neutral & Cost \\
\hline $3=$ Major Benefit & \multirow{3}{*}{$\begin{array}{l}0=\text { No Influence/ } \\
\text { Impact from options }\end{array}$} & $-3=$ Big Cost \\
\hline 2 = Medium Benefit & & $-2=$ Medium Cost \\
\hline 1 = Major Benefit & & $-1=$ Small Cost \\
\hline
\end{tabular}

a. Benefit:

Relatively non-existent, just the absence of any additional costs for the Regional Government to issue a new regulation related to institutional and capacity strengthening of DPMPTSP.

b. Cost:

- Coordination between DPMPTSP and the Technical Service is not going well;

- Inefficient licensing services;
- The level of business confidence in DPMPTSP declines

The various impacts that arise if no action is taken are risks that must be faced by the Government. This risk can be a measurement baseline if it is to be evaluated in the future.

2) Alternative Option II: DPMPTSP Institutional Strengthening

If alternative option II, namely DPMPTSP Institutional Strengthening is taken, the estimated benefits and costs received by the stakeholders are:

a. Benefits:

- DPMPTSP coordination with the Technical Office has increased;

- Licensing services are becoming more efficient;

- The efficiency of licensing services also has an impact on increasing service speed;

- Legal certainty for businesses increases;

- The level of business confidence in DPMPTSP has increased (indirect impact).

Table 4.

Benefit and Cost Analysis of Each Option

\begin{tabular}{|c|c|c|c|c|}
\hline Group/ Stakeholder & Benefit/Cost & Alternative I & Alternative II & Alternative III \\
\hline \multirow[t]{6}{*}{ Local Government (DPMPTSP) } & Coordination with the Sector Agency & -2 & +3 & 0 \\
\hline & Efficient Licensing Service & -3 & +2 & +2 \\
\hline & Implementing Apparatus Training & 0 & +1 & +1 \\
\hline & Infrastructure Availability & -2 & +2 & +2 \\
\hline & $\begin{array}{l}\text { Trust Level of Business World towards } \\
\text { licensing services }\end{array}$ & -3 & +3 & +2 \\
\hline & Infrastructure Procurement Budgets & 0 & 0 & -2 \\
\hline Related Sector Agency & Coordination of supervision with DPMPTSP & -2 & +3 & 0 \\
\hline Bappeda & $\begin{array}{l}\text { DPMPTSP Institutional Strengthening } \\
\text { Program Planning }\end{array}$ & 0 & +2 & +2 \\
\hline Legal Section & Cost of Local Regulations Making & 0 & -2 & 0 \\
\hline \multirow[t]{3}{*}{ Business World } & Licensing procedure & -2 & +2 & +2 \\
\hline & Legal certainty on licensing & -2 & +3 & +2 \\
\hline & Licensing Processing time & -3 & +3 & +3 \\
\hline \multicolumn{2}{|c|}{ Total Net Benefit (Benefit and Cost) } & -19 & +22 & +14 \\
\hline
\end{tabular}

Notes:

Alternative I: Do nothing / Leave it as it is

Alternative II: DPMPTSP Institutional Strengthening

Alternative III: DPMPTSP Capacity Strengthening 
b. Cost:

Costs for making regulations on institutional strengthening of DPMPTSP (Regent Regulation and SOP of Licensing services)

\section{3) Alternative Option III: DPMPTSP Capacity Strengthening}

If alternative option III is taken, the estimated benefits and costs that arise if alternative option III is taken are:

a. Benefits:

- Licensing services are becoming more efficient.

- The efficiency of licensing services will also have an impact on increasing service speed.

- Legal certainty for businesses increases.

- The level of business confidence in DPMPTSP increases.

b. Cost:

The cost that arises is the infrastructure procurement budget (system, hardware, etc.) that is borne by the regional government.

Based on the calculation of the benefit costs of each action option received by stakeholders, it can be concluded that the second alternative (Institutional Strengthening DPMPTSP) provides the greatest net benefit when compared to the two other alternatives. The party most affected by the costs of the second alternative option is the Legal Department because they must budget the costs of drafting the law. While other stakeholders receive greater benefits than the costs to be borne. However, when viewed from the positive externalities that can be generated:

a. Increasing the efficiency of licensing services;

b. Increased economic activity mainly moves to the formal sector, thus creating a multiplier effect on socio-economic activities;

c. people's income increases, so that people's purchasing power increases;

d. GRDP increases;

e. Increased public income increases, the impact on tax payments which is government revenue

The institutional strengthening of DPMPTSP starts from the delegation of authority from the Regional Heads to the Heads of DPMPTSP. This condition is part of the mandate of Law Number 23 of 2014. By making full authority delegation to DPMPTSP, licensing services become centralized, so that the role of DPMPTSP as a one-stop integrated service center is more optimal.

To support the institutional strengthening of the DPMPTSP, the involvement of the Technical Agency in preparing the recommendations must also be limited. One effort that can be done is to place technical human resources in DPMPTSP. This is in line with the results of Wimmer's research (2002, p. 96) which states that one of the things that can support the implementation of e-government is providing access to public services through one door even though the service is provided by several institutions.

The development of DPMPTSP institutional licensing services needs to be supported by regulatory simulations (Setiadi, 2018, p. 328). The proposed improvement model is the preparation of the NSPK regulatory format. To equalize the NSPK format, it is necessary to develop a Scripts Guideline/Format for the preparation of the NSPK issued by the Ministry of Law and Human Rights which then becomes a reference for all Ministries/ Institutions.

Larasati (2016) states that to overcome the problems of public services, especially licensing services, the government needs to improve the competence of the implementing apparatus to provide good services to the public. HR capacity building can be done through the provision of education and training and technical guidance to create apparatuses that can meet the needs of the community by carrying out their duties properly.

Technology support is one way to accelerate the implementation of investment licensing by optimizing the use of digital technology (Sari, 2018). Therefore, increasing the quality and quantity of infrastructure facilities needs to be done to support DPMPTSP's institutional performance in implementing electronic-based licensing services.

The application of institutional optimization should also be included with performance appraisal is an activity that is very important for an organization because the results of this assessment can be used as a measure of organizational success in achieving its mission (Ilhamsyah, 2013). The existence of this performance appraisal is useful to find out important aspects that must be improved in the framework of service policy implementation namely the aspects of communication, disposition, bureaucratic structure, and human resources (Takumansang, 2013).

\section{ConClusion}

Referring to the results of the analysis above, the formulation of strategies for optimizing DPMPTSP institutions can be done through:

1. Delegation of authority for licensing services to DPMPTSP;

2. Prepare guidelines for NSPK manuscripts;

3. Updating DPMPTSP institutional regulations 
that contain DPMPTSP Duties and Functions including coordination with the Technical Service;

4. Making legislation to implement regulations on institutions;

5. Updating of SOP for licensing services;

6. Placement of technical human resources in DPMPTSP;

7. Development of facilities and infrastructure to support electronic-based services

To carry out these alternative actions, a strong commitment from the Regional Head is needed, as well as close coordination between DPMPTSP and the related Technical Agency.

\section{ACKNOWLEDGMENT}

The author would like to thank the experts who are willing to participate as the informants.

\section{REFERENCES}

Amsyah, Z. (2001). Manajemen Sistem Informasi. Jakarta: Gramedia Pustaka Utama.

Biro Hukum Kementerian PPN/Bappenas. (2011). Pengembangan dan Implementasi Metode Regulatory Impact Analysis (RIA) untuk Menilai Kebijakan (Peraturan dan Non Peraturan) di Kementerian PPN/Bappenas. Jakarta: Biro Hukum Kementerian PPN/Bappenas.

BKPM. (2019). Investment Realization in the First Quarter of 2019 Reached Rp 195.1 Trillion, Increased by 5.3\%. Retrieved from https:// www.bkpm.go.id/images/uploads/berita/ file_upload/BKPM_Press_Release_Investment_ Realization_Q1_2019.pdf

Bünte, M. (2008). Indonesia's protracted decentralization: Contested reforms and their unintended consequences. In M. Bünte \& A. Ufen (Eds.), Democratization in Post-Suharto Indonesia. Retrieved from https://www. taylorfrancis.com/books/e/9780203934760/ chapters/10.4324/9780203934760-12

Corcoran, A., \& Gillanders, R. (2015). Foreign direct investment and the ease of doing business. Review of World Economics, 151(1), 103-126. https://doi.org/10.1007/s10290-014-0194-5

Hartono, \& Hartomo, D. D. (2016). Faktor-faktor yang Mempengaruhi Perkembangan UMKM di Surakarta. Jurnal Bisnis Dan Manajemen, 14(1), 15-30. https://doi.org/10.20961/jbm. v14i1.2678

Hidayat, F., Sutomo, \& Sunarko, B. S. (2018). Implementasi Pelayanan Terpadu Satu Pintu (PTSP): Pendelegasian Kewenangan Setengah Hati (Studi terhadap Penyelenggaraan PTSP di Badan Pelayanan Perizinan Terpadu Kabupaten Banyuwangi). POLITICO, 18(1), 144-163. https://doi.org/10.32528/politico. v18i1.1377

Hodgkinson, I. R., Hannibal, C., Keating, B. W., Chester Buxton, R., \& Bateman, N. (2017). Toward a public service management: past, present, and future directions. Journal of Service Management, 28(5), 998-1023. https://doi. org/10.1108/JOSM-01-2017-0020

Ilhamsyah. (2013). Reformasi Birokrasi Pada Pemerintah Kabupaten Kotabaru (Studi Terhadap Kualitas Pelayanan Pada Badan Pelayanan Perijinan Terpadu Dan Penanaman Modal). Jurnal Ilmu Politik Dan Pemerintahan Lokal, 2(1), 53-72. Retrieved from https:// www.neliti.com/id/publications/101826/ reformasi-birokrasi-pada-pemerintahkabupaten-kotabaru-studi-terhadapkualitas-p

Jaakkola, E., Helkkula, A., \& Aarikka-Stenroos, L. (2015). Service experience co-creation: conceptualization, implications, and future research directions. Journal of Service Management, 26(2), 182-205. https://doi. org/10.1108/JOSM-12-2014-0323

KPPOD. (2014). Badan Pelayanan Terpadu Satu Pintu (BPTSP) di Provinsi DKI Jakarta: Perspektif Kewenangan dan Kelembagaan. Retrieved from https://www.neliti.com/publications/259/ badan-pelayanan-terpadu-satu-pintu-bptspdi-provinsi-dki-jakarta-perspektif-kewe

KPPOD. (2016). Reformasi Kemudahan Berusaha: Evaluasi Pelaksanaan Paket Kebijakan Ekonomi di Daerah. Jakarta: KPPOD.

Kusdi. (2009). Teori Organisasi dan Administrasi. Jakarta: Salemba Humanika.

Larasati, P. A. (2016). Pengembangan Aparatur Berbasis Kompetensi dalam Meningkatkan Kualitas Pelayanan Perizinan di Unit Pelaksanaan Teknis Pelayanan Perizinan Terpadu (UPT P2T) Badan Penanaman Modal Provinsi Jawa Timur. Kebijakan Dan Manajemen Publik, 4(3), 243-255. Retrieved from http://journal.unair.ac.id/ KMP@pengembangan-aparatur-berbasiskompetensi-dalam-meningkatkan-kualitaspelayanan-perizinan-di-unit-pelaksanaanteknis-pelayanan-perizinan-terpadu-(uptp2t)-badan-penanaman-article-10951-media138-category-8.html

Mardiasmo. (2009). Akuntansi Sektor Publik. Yogyakarta: Andi.

Mulyadi, M. B. (2018). Pengaruh Kualitas Pelayanan Perizinan Terpadu dalam Meningkatkan Investasi dan Pertumbuhan UMKM. Jurnal 
Hukum Mimbar Justitia, 4(1), 112-127.https:// doi.org/10.35194/jhmj.v4i1.293

Nee, V. (2003). The New Institutionalism in Economics and Sociology (No. 4). Retrieved from https:// www.economyandsociety.org/wp-content/ uploads/2013/08/wp4_nee_03.pdf

OECD. (2008). Introductory Handbook for Undertaking Regulatory Impact Analysis (RIA). OECD.

Osborne, S. P., Radnor, Z., Kinder, T., \& Vidal, I. (2014). Sustainable public service organisations: A Public Service-Dominant approach. Society and Economy, 36(3), 313-338. https://doi. org/10.1556/SocEc.36.2014.3.1

Rangriz, H., \& Soltanieh, F. (2015). Exploring the Effects of Organizational Capabilities and Managerial Competencies on the Organizational Effectiveness. Journal of Strategic Human Resource Management, 4(2). Retrieved from https://ssrn.com/abstract $=2655470$

Raymond, C. P., Hatane, S., \& Hutabarat, J. (2015). Analisis Kualitas Sumber Daya Manusia, Kualitas Pelayanan, Kinerja Organisasi, Kepercayaan Masyarakat dan Kepuasan Masyarakat (Studi Kasus: Dinas Kependudukan dan Catatan Sipil Kabupaten Nabire). Jurnal Teknologi Dan Manajemen Industri, 1(1), 1-8. Retrieved from https://ejournal.itn.ac.id/ index.php/jtmi/article/view/245

Republik Indonesia. (2019). Nota Keuangan Beserta
Rancangan Anggaran Pendapatan dan Belanja Negara Tahun Anggaran 2019. Republik Indonesia.

Sari, P. P. (2018). Pemanfaatan Teknologi Digital Sebagai Percepatan Berusaha oleh Ekonomi Kreatif. Jurnal Komunika: Jurnal Komunikasi, Media Dan Informatika, 7(3), 135-144. https:// doi.org/10.31504/komunika.v7i3.1824

Setiadi, W. (2018). Simplifikasi Peraturan Perundang-undangan dalam Rangka Mendukung Kemudahan Berusaha. Rechtsvinding, 7(3), 321-334. Retrieved from https://rechtsvinding.bphn.go.id/ejournal/ index.php/jrv/article/view/288

Takumansang, C. M. (2013). Implementasi Kebijakan Pelayanan Izin Mendirikan Bangunan (IMB) di Badan Pelayanan Perizinan Terpadu Kota Manado. Acta Diurna Komunikasi, 2(4). Retrieved from https://ejournal.unsrat.ac.id/ index.php/actadiurnakomunikasi/article/ view/2668

Vogiatzoglou, K. (2016). Ease of Doing Business and FDI Inflows in ASEAN. Journal of Southeast Asian Economies (JSEAE), 33(3), 343-363. Retrieved from https://muse.jhu.edu/article/647393

Wimmer, M. A. (2002). A European perspective towards online one-stop government: the eGOV project. Electronic Commerce Research and Applications, 1(1), 92-103. https://doi. org/10.1016/S1567-4223(02)00008-X 